\title{
A Comparative Study of Urban Spaces Between Samarkand City in the Timurid Period and Isfahan City in the Safavid Period
}

\author{
Shahin Mirhosseini Vakili \\ Department of Urbanism, Faculty of Art, Architecture and Urbanism, Kerman Branch, Islamic Azad University, Kerman, Iran \\ Email address: \\ Vakili.shahin@yahoo.com \\ To cite this article: \\ Shahin Mirhosseini Vakili. A Comparative Study of Urban Spaces Between Samarkand City in the Timurid Period and Isfahan City in the \\ Safavid Period. Landscape Architecture and Regional Planning. Vol. 5, No. 3, 2020, pp. 46-54. doi: 10.11648/j.larp.20200503.11
}

Received: January 21, 2020; Accepted: March 4, 2020; Published: October 27, 2020

\begin{abstract}
The present study aimed to study the evolution of urban spaces in the Timurids and Safavids. In present study, first, Samarkand city built in the Timurid era and Isfahan city built in the Safavid era were compared in terms of urban spaces and then, the differences, similarities and the effects of each city on the other one were mentioned. Finally, the main components of urban space were studied in the two cities. In this regard, with a descriptive-historical approach, data were collected using historical sources and texts, images, maps, and the results of studies carried out by contemporary researchers. The two cities of Samarkand in the Timurid period and Isfahan in the Safavid period had the same natural, climatic, social, cultural and economic characteristics, which had significant effects on the formation of urban spaces in both cities. The features of Timurid urban spaces can be mentioned as several principles: the establishment of gardens within and outside the city, the construction of main urban roads using various buildings and varies land uses, the spread of urban complexes using a square. Then, in the Safavid era, urban spaces were flourished by following the Isfahan school. Then, with the development of social, political, economic and cultural grounds and composition of them in the urban spaces, the ideal city of Isfahan was realized in the Safavid era. It seems that the principals of physical and semantic formation of urban spaces of Isfahan city in the Safavid era had aimed to create the heavenly paradise in the present world.
\end{abstract}

Keywords: Urban spaces, Samarkand, Timurid Period, Safavid Period

\section{Introduction}

Like the Mongols, the Timurids took the government by creating a lot of chaos and killing many peoples in different parts of Iran, but they were quickly attracted to the Iran's culture and civilization [29].

Since its main capital was Samarkand, artists, craftsmen, scholars and famous persons of the conquered cities were moved to Samarkand, especially many artists were moved from Shiraz to there. Timur chose Samarkand as his capital for some reasons. Samarkand is a beautiful city that has been mentioned as good city in travelogues. For example, Estakhri says, "Samarkand has the best climate, soil and the land... and in it, people permanently try to acquire knowledge and grace and they are generous. In Transoxiana, there is no land better than Samarkand". Samarkand city has a very ancient historical and cultural background. It has been important and had significant economic prosperity due to its very favorable climatic conditions, as well as the presence of important trade routes, especially the Silk Road [34].

In the early sixteenth century (the tenth century $\mathrm{AH}$ ), the Safavids established a Shiite government in Iran that was considered to be a very important event not only for Iran, but also for its neighbors and, in general, the outside world [10]. It seems that according to the Safavid belief, the city is a place for the realization of ideals and beliefs. It is a place for the presence and expression of symbols (market, Ivans, garden, axis, square, etc.) which represent the power of the ruling state and give identity to the city. The preservation and stability of these symbols were of particular importance. The most important symbols were gardens and vegetation. Therefore, the Safavid has provided the necessary ground for the stability of 
gardens and vegetation. Respect for human equality, respect for followers of the religions having religious texts and creation of suitable collective spaces (Naghsh-e-Jahan Square and Chaharbagh Street) are considered as the most effective factors in strengthening social relations in Safavid garden city. It seems that the Safavid has paid significant attention to the historical core of the city due to their belief in the vitality of the whole city, the prevention of the transhuman expansion of the city and the use of the economic (market) and social potentials (Atiq Square and Jame mosque) of the ancient nucleus (Seljuq) of the city [20].

\section{Urban Spaces in Iran}

In Iranian cities, there were many spaces which were built with the purpose of endowment for the public use and to pursue satisfaction in God. A glance at the list of public buildings in the history of Iran shows that such buildings have been always built in order to meet the needs of inhabitants and had two distinct aspects:

1. Providing free services to those without financial ability

2. Providing free services to passengers (Ibn as-sabil)

The civilization of Iran faced ups and downs during its long historical period and experienced a variety of collective activities in spaces. Some of these main spaces were those located in the cities and known to the people [39]. The design principles of urban spaces in Iran include old or interior, middle and new parts and the entire urban complex. Among them, the principles of spatial organization are more visible in the old (interior) and partly in the middle parts. These principles are including the principles of spatial integration, the continuum between residential units and urban elements, spatial enclosure, scale and proportion (human scale), territory and composition [41].

\section{Samarkand City in the Timurid Period}

At the end of the eighth century, Timur chose Samarqand city as his capital and has made great efforts to construct and develop it. He wanted to make it the largest city in the world. The Zarafshan (Kuhak) river was located on the north of Samarkand, and a large number of watercourses and streams irritated the areas around the city, and because of these rivers and watercourses, this city has been always lush [15].

Traditional methods influenced by the Islamic mystic perspectives, as well as modern methods, were more commonly used in the construction of mosques and schools, but in public buildings, the modern methods were applied [32]. Generally, in this period, the buildings had the forms and structures popular in the Seljuk period, but due to the dominance of Mongols, new scale and magnificence appeared in them, and decoration of the buildings has been specially paid attention. Most of the buildings were constructed in a 4iwan form with tall iwans having the portals ornamented by Muqarnas and the ornaments mainly included very beautiful and magnificent Qashani tileworks, especially "Seven Colors" (Haft Rang) and Moaraq (flora) tiles [7].

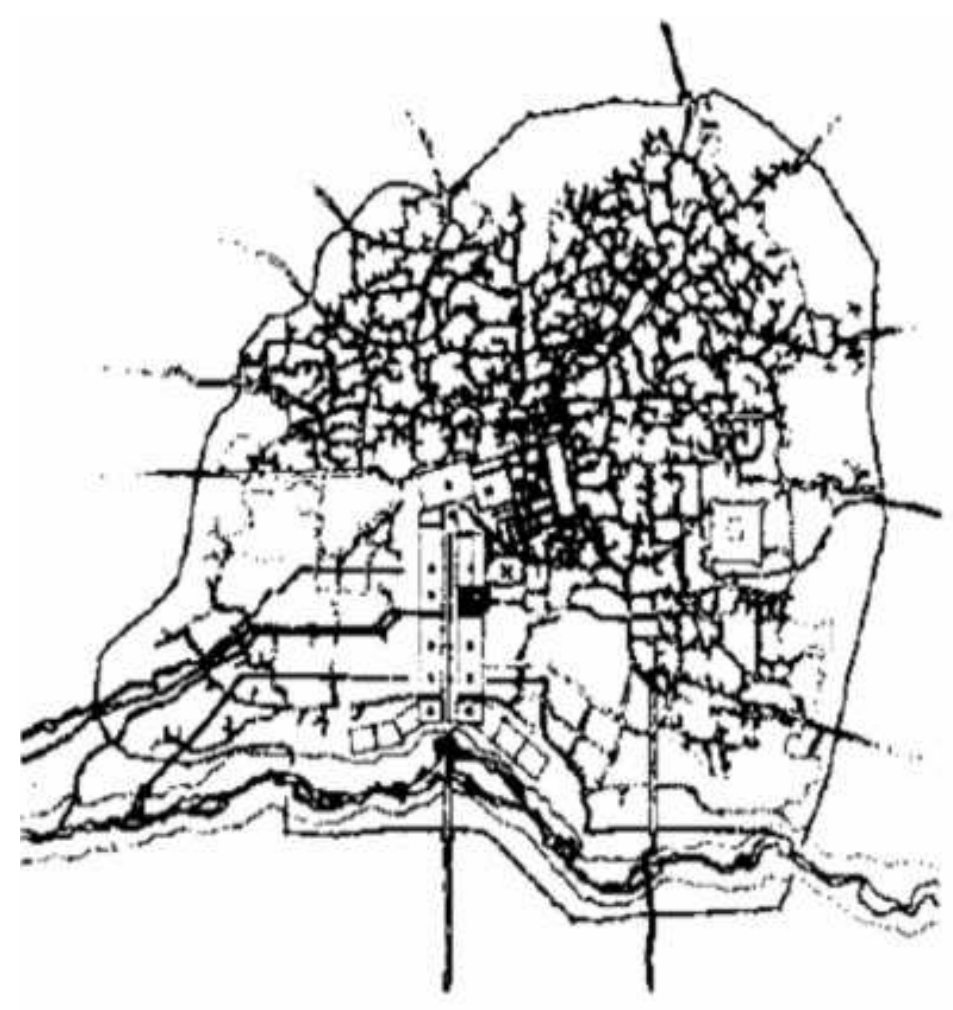

Figure 1. Isfahan Downtown in Safavid Period.

The enthusiasm and cultural genius of the Timurians

brought a new definition for many aspects of the urbanization 
and urbanism of that era. Changes in the architectural structure of many buildings of this age, along with social, cultural and religious changes, make a new form of urbanism. The growing support of art and artist and the creation of new places for the spread of culture and art along with religious beliefs influenced by the Sufi thought of that time undoubtedly make the Timurid urban spaces one of the milestones of urbanism [28].

\section{Isfahan City in the Safavid Period}

The political and social changes that gradually took place in Iran after the Mongol invasion have led to continuous changes in the architecture and urbanism of Iran. Among these changes, those began from the reign of Shah Tahmasb and reached their peak points in the reign of Shah Abbas, should be considered as a milestone leading to the establishment of the Isfahan School. The most important indicators of this school were the concentration of power in the king, bureaucracy and government involvement in most of the activities. This concentration and relative political and economic stabilities in the long period provided the possibility of large-scale development and urbanization activities [14].

It seems that the physical identity of the Isfahan garden city follows the Iranian garden and is the result of the interaction between water, soil and plant, along with the semantic, geometric and aesthetic system (physical organization and landscaping) and the functional system, from the micro (components) to macro scale. The semantic system effective in the Isfahan garden city during the Safavid era is the allegory of paradise because of utilizing general and specific symbols in order to define the specific sense of place for the Safavid garden city. In the Isfahan garden city, the principles of Isfahan school derived from intellectual teachings of the Isfahan school, along with the use of gardens (as the main elements constituting the city) and landscaping of urban spaces (Chaharbagh street) with a row of trees (in accordance with the principles of Iranian garden landscaping) have been used as a practical way to define a special semantic system for this city, as mentioned in various texts remained from that era. The urban design of Isfahan during the Safavid period is "the definition of urban center of gravity" and "urban spaces in the defined connection paths" [38].

\section{Similarities Between Samarkand City in the Timurid Period and Isfahan City in the Safavid Period}

In this section, the Timurid period in Samarkand city and the Safavid period in Isfahan city, which were two main periods in the history of Iran, have been mentioned. There are some similarities between these two cities: both of them were of large and densely populated cities, and both of them were formed besides the river, and the river, as a natural factor, played a significant role in the formation of many gardens in these two cities. In addition to natural factor, due to other factors, Isfahan gardens were influenced by Samarkand city [42].

\section{Differences Between Samarkand City in the Timurid Period and Isfahan City in the Safavid Period}

The main difference between Samarkand city and Isfahan city during the reign of Shah Abbas is that there is no comprehensive plan in the medieval plan of Samarkand. Although each of the gardens was designed according to the geometric style of Iranian garden, their relationships with each other and the city were formed coincidentally [26]. The order and spatial organization governing the Isfahan garden city are geometric and pre-designed, while spatial organization governing the gardens in Samarkand (the areas within and outside the fortification) was organic and formed over time and during different periods, with the emphasis on connection goals and consistent with its historical identity [19].

\section{The Effects of Samarkand City in the Timurid period and Isfahan City in the Safavid Period on Each Other}

It seems that the garden cities built in the Timurid period (Herat and Samarkand) have also been effective in the design of the Safavid garden cities. A century after the fall of the Timurid dynasty, Shah Abbas ordered the reconstruction of Isfahan by constructing new neighborhoods outside the main city (according to the Timurid style in Herat and Samarkand). Shah Abbas was born in Herat in $978 \mathrm{AH}$ and lived there until the beginning of his reign (18 years old). Most likely, the Herat city, which included many gardens, played a key role in forming his thought of utopia. Shah Abbas probably considered the garden of Herat as the primary pattern when he ordered the development of Isfahan city and the construction of Chaharbagh Street with the use of Iranian garden pattern [6].

Main streets in the Iranian cities

In Iran, the connection paths have an exquisite and special status according to the design pattern of Iranian historic cities and the design conditions and lifestyle of people. These paths were completely in line with the habitat and livelihoods of the people and before the industrial revolution and the emergence of its complications, they easily responded to the daily affairs of the cities. But, from the beginning of the 16th century and the Renaissance which coincided with the peak of the Safavid dynasty in Iran, the new style of urban design, called Isfahan style, was raised. Mainly, emergence of the phenomenon of street in Iran can be studied in two historical periods: peak of the Safavid empire and the concept of street in the Qajar period and afterwards [23].

The main routes of Samarkand city during the Timurid period

According to the historical texts written in the Timurid era and on Samarkand city, some connection axes have been 
described, which can be considered as the main axes of this city. In this period, one of the most important and most innovative measures taken in the city was the construction of street. There were three types of streets in Samarkand city and its surrounding areas: street with economic and commercial functions, streets concluding gardens and sometimes monuments and graves, which were located outside the city, and the streets that merely connected different regions and points of the city. The third type was constructed in an organic form and with the buildings on its sides [28].

Baber speaks of a street that connects Samarkand and its gardens to the eastern part of the city. This street was a promenade and there were trees on both sides of it [42].

Due to the lack of suitable spaces for market activities in Samarkand, Timur decided to construct a street in the center of the city. In describing the construction of this complex, Kelavikho (1998) writes:

Every year, from China, India, and the Tatar land, different types of goods are brought to Samarkand, because the territories around Samarkand are considered as the major commercial centers. But, there was no place within the city to store these goods in a proper and appropriate manner as well as to exhibit and offer them for sale. Thus, Timur ordered the construction of a street passing through Samarkand, as well as the construction of shops on the two sides of it for selling all kinds of goods. This new street crossed the city. The houses were still not destroyed when the builders came and built that wide street, and built the shops on both sides of it. A stone bench, with a white stone slab on it, was constructed in front of each shop. Each shop had two rooms. And above that street, there was an arched and dome ceilings, which had openings for lighting. Immediately after the construction of shops, merchants came there to sell their goods. At various intervals along the streets, the fountains were built. The city council was responsible for these constructions, and there was no shortage of worker.

This indicates the tourism and commercial activities in these areas, especially in the body of the main axes. Moreover, secondary elements have been used in landscaping of these axes. According to Kelavikho's description, "... some villages are developed in a distance of one and half parasang and sometimes two parasang to the city, and the city is located among them." And these routes connected the areas around the city to the city center (Registan Square)" [16]. Therefore, a number of gardens on the sides of the route were residential. Also, these routes had a connecting role. Some of these routes have ended in government gardens, as Baber refers to the magnificent street that starts from Firooz or the Firoozi gate and ends in the Delgosha garden [15].

The main routes of Isfahan city during the Safavid period
It seems that the history of using straight and pre-designed streets, with rows of trees planted on both sides, is rooted in the garden cities of the Timurid era, and in the Safavid era, this street style was used in a different form (street, as multipurpose public space) in Chaharbagh street, Isfahan. After construction of Chaharbagh street in Isfahan, this pattern of street (Chaharbagh) was used in other cities like Mashhad and Shiraz. Chaharbagh Steet was constructed according to a geometric design and plan. It intersected the Zayandehrood axis, and made the four main parts of the city (Chaharbagh), and royal gardens were placed on both sides of the street. With the construction of si-o-se-pol bridge, Chaharbagh Street stretched to the Soffe mountain in the south of the city, and at the end of Chaharbagh, there is a large and unique garden called Hezarjarib Garden (Khalad Sani or Shah Abbas Paradise) [5].

The purpose of the design and construction of Chaharbagh Street was not just to design a street with a typical function in Isfahan city during the Safavid era, but to provide access to the gardens and kushks (kiosks) located there, in addition to its functional aspects. In fact, it was a promenade. In addition to being an arena for the formation and strengthening of social interactions, Chaharbagh has been a good place for recreation, entertainment, sports and spending leisure time for various groups of people. These features have made many personal and collective memories and strengthened the sense of belonging to this place. Also, this historical axis, as one of the prominent symbol giving the identity to the historic city of Isfahan, has played a major role in reviving citizens' collective identities [36].

There were various commercial, tourism, communication, educational, religious, government and residential activities on Chaharbagh Street in Isfahan and the gardens surrounding it. Skandar beik Turkman mentioned to the "Vardavar" festival and Janabadi mentioned to the pubs and coffee shops on this street. Sharden referred to the presence of two guest houses, namely Darvishan Heidari and Nematollahi on this street, and most of the travelers pointed to the circulation of people on this street. Also, Chaharbagh Street of Isfahan was used as a highway during its time, and in terms of function, it connected the southern part of the Safavid royal court to the upper part of the city, the Hezarjarib Garden. In Chaharbagh Street, the most obvious element is the rhythmic repeating of the portals of gardens, which were as symmetric as possible. This magnificent view along with the stream of water, ponds, fountains and trees could be seen from the top of the Jahannama mansion at the north end of Chaharbagh Street as well as top of the portals of the gardens located on both sides of the street. On the ground floor of these mansions, there were the portals and on the upper level, there were iwans that were open to the street.

Table 1. Comparison of the main streets of Samarghand city in the Timurid era and Isfahan city in the Safavid era.

\begin{tabular}{llll}
\hline & Main activity and function & Design pattern & Natural and artificial elements \\
\hline \multirow{3}{*}{ Samarkand } & a) Commercial & & a) Trees on both sides \\
& b) Connecting & Organic & b) Fountains \\
c) Tourism & & c) Stone benches \\
\hline
\end{tabular}




\begin{tabular}{llll}
\hline & Main activity and function & Design pattern & Natural and artificial elements \\
\hline d) Residential & & \\
a) Social & & \\
b) Connecting & Straight and pre-designed & a) Trees on both sides \\
Isfahan & c) Tourism & b) Stream, ponds, fountains \\
& d) Commercial & & \\
e) Residential & & \\
f) Governmental & & & \\
\hline
\end{tabular}

\section{Iranian Garden (Persian garden)}

The Iranian Garden is a harmonious and beautiful collection formed by a wise, sophisticated, eye-catching composition of water, plant, path, shadow, color, space and an architecture based on the gentle geometry. The inspiring visual combination of such beauty and perfection can be seen on most of Iranian visual arts. Like architecture, poetry, painting, music, and other Iranian artworks, it enjoys exquisiteness and subtleties in the framework of tradition and relies on the unity in diversity and diversity in unity.

\section{Gardening during the Timurid period}

The attention paid to art during the reign of the Timurid reached its peak point during the period of Abu al-Ghazi Hossein Baighara. At the court of Herat and in the environment of these palaces and gardens, famous painters such as Behzad and Shah Mozaffar created their best works. The best examples of Behzad's work are the paintings in two manuscripts: one of them is Khamseh of Nizami kept in the British Museum and another one is a manuscript of Boostan, held in the library of Cairo, and includes four miniatures with Behzad's signature. The delicate artworks of these painters reflect the Iranian garden and royal palaces, as well as the royal festivals of this century. Paying attention to Samarkand and Herat gardens reveals that these gardens had a great influence on gardening in other areas as well as in the following periods. The typical kind of these gardens was used in both east and west. The Timurid garden has been influenced in terms of many general features, including the presence of a fence, a kushk (kiosk), a fountain, the use of aromatic and medicinal flowers and plants, etc. by eastern gardens and it was different from them in some of the minor characteristics, including fountain geometry, the method of dividing plots, etc.

The Timurid, while benefiting from the traditions of Iranian gardens, influenced the Indian and Mongolian gardens and Safavid Iranian gardens.

Top Tips in Samarkand Gardens in the Timurid Period:

a) The wide area of the Timurid gardens and the design of garden space with great proportions

b) The enclosure of the garden with tall walls and the portals decorated with blue and gold Qashani tilework

c) Following the Iranian Chaharbagh tradition and dividing the space into four parts

d) Using a main stream in the garden

e) Selecting a piece of land that is naturally steep or creating an artificial hill to ensure that the water flows satisfactorily

f) Using streets and rectangular little gardens in the garden g) Using tents in the gardens

h) Creating artificial hills in gardens [27].

i) The gardens were public

j) Using parkways in the garden

k) The most common gardens were the garden with a central kushk (kiosk)

1) There is a kushk or a palace in the garden (expensive construction and ornaments)

m) Creating ponds and plenty of fountains

n) Using gardens as a place for official celebrations and festivals [15].

Gardening in the Safavid period

Muslim architects of this period had tried to visualize all the features of the paradise mentioned in Quran in the Iranian garden and to design it as an allegory of the paradise. In this regard, they used the titles related to paradise in the naming of gardens, and even called some gardens "paradise" [42]. The Iranian garden has been established on the level above the garden level to create the proper and favorable landscape. Due to this, the attention of the observer is not focused solely on the inner landscape and the beauty of the garden itself, but he/she is attracted to the outside the garden and the landscape beyond the garden is one of the goals of the Iranian garden. Reviewing drawings, maps and historical descriptions of the Safavid gardens show that the nature constitutes the main part of the Persian garden and the garden landscape stretched out beyond the wall was specific feature of the Iranian garden [3].

The trapezoidal and octagonal plans were used in the Khargah garden at the beginning of Abbasi Charbagh (Abbasi parkway) and Goldasteh Garden on the eastern side of the Bolbol garden. There is no report on such innovation in the plans used in the gardens in Samarkand and the reports refer to the square or rectangular plans of the gardens.

The features of the Safavid gardens are as follows:

a) Designing gardens in the form of Charbagh (parkway) and placing tree, kushk, or in most cases, pond (with rectangular, octagonal or semicircular form) at the intersection of Charbagh.

b) Connecting the two interior (building or palace) and exterior (garden) spaces, including construction of springhouse and fountains with jet of water and flower pods inside the building [31]. A very good example of this can be seen at Chehelsotun Palace in Isfahan.

c) Using trees in four to eight rows

d) Removing the garden fence and using it as a public promenade and connection routes [24].

e) Creating small nests and cages for birds under the influence of Chinese designs 
f) Using watercourses with turquoise tiles

g) Using lattice enclosing walls

\section{Urban squares in Iran}

The role of the square as a center for urban gatherings, trade and religious and government ceremonies is undeniable, but the development and growth of the square in post-Islamic urbanization can be seen by the formation of semi-autonomous neighborhoods with the center of the mosque, market and square. They appeared according to the ethnicity or occupation of the inhabitants. In these cities, the main squares appeared as a major place for religious gathering due to the presence of the Jame'e mosque in it, and they gradually became multifunctional place [13].

The squares of Samarkand city in the Timurid period

According to Wilber and Golembek, in the Timurid era, examples of urban complexes based on a squarecould be found. Such squares, like the Registan Square, were cultural and commercial squares. In ancient Iran, the main squares played a significant role in the social lives of the Iranian people and were somehow considered as the heart of the community. So many important events took place in the main square of the city. In reviewing a map of Samarkand city in the eighteenth century, the city was shown with six gates. A gate on the west of the Shahzand complex, which was known as the Iron Gate in the fifteenth century, was connected to the center of the city with a long street. Here, there was a great intersection. In the southwest of this center, and at the near distance, there was a large Registan Square [43]. The name of this square refers to its ancient situation. Registan is a land full of pebbles and gravels. Registan was the central square of Samarkand city, and from the beginning, there was no school around it.

At that time, the rulers used the Registan square to declare government announcements, and the people gathered in the square to hear and know the ruler's orders. The announcements were declared by public crier. Also, the Registan square was also a place for public celebrations. In the part of the square, there was a wooden structure for punishment and execution in public. Moreover, it was a place for collecting military forces for war, and commercial land uses were also found around the Registan Square. In this square, as in the previous periods, a new emphasis on the scale takes place. Emphasis on the facades and placing of minarets in the corner and omitting any connection between the square construction and other buildings are of the features of the style governing in the Timurid era. Increasing the scale of buildings led to simplification of form and shape of buildings. Nevertheless, concentrating cultural complexes of schools in a place besides each other and construction of such a social and cultural space are considered as a new doing in providing such spaces in the city. Although, according to Wilber, the function of the Registan Square was economic, all the major and most important routes of Samarkand led to the Registan Square.

In different periods, the rulers reduced and increased the importance of the Registan Square with their policies. Since that time up to now, the Registan Square has been remained as the main center for social life. The schools around Registan Square have been built in different times and by two rulers.

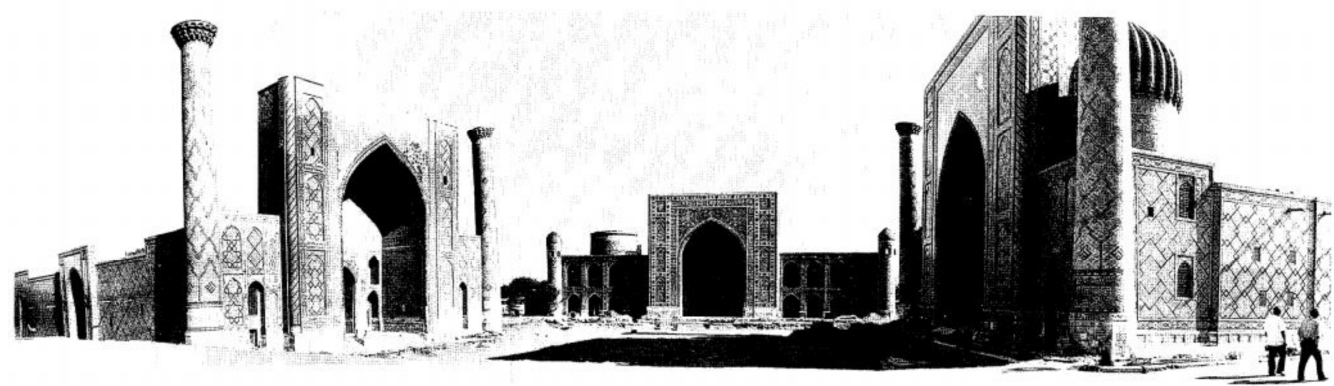

Figure 2. Rigestan Square in Samarkand.

\section{The squares of Isfahan city in the Safavid period}

The "designed" or "ordered" urban squares, which were commonly used from Safavid to late Qajar, had walls constructed in accordance with the function of square. Often, in such squares, government ceremonies were held [1]. The Naqshhe Jahan Square was built in the Safavid era, which is a space enclosed by architectural structures with different uses such as bazaar, mosques, sports fields, and government institutions. They are not only complement and interconnected with each other but also create a common body for the greater presence of people [13]. The Naqshe Jahan Square was constructed as a pre-designed space with the length of 505 meters and width of 160 meters, and four markets were founded on it four sides. This square has a regular geometric plan in the form of a rectangle with a north-south direction. On four sides of it, four buildings were constructed, including the Aali Qapu Palace in the west as the place for king, the portal of the Qeysarie market in the north, the Sheikh Lotfollah Mosque in the east as the religious and government place, Abbasi Jame'e mosque in the south as a place indicating the social and public power. These four buildings, in combination with the market, which were constructed in the form of uniform arches on two floors surrounding the open space of the square, formed the enclosing body of the square. The first floor consisted of commercial shops, and the second floor was constructed in the form of iwans and small chambers for work and rest of the marketers [37].

The Naqshe Jahan Square of Isfahan is the only major urban space that relatively remains with its main form, and 
can be discussed as an example of urban space on a city scale. Haynes Goube believes that Shah Abbas has used the Kohne Square of Isfahan as the pattern to design Naqshe Jahan Square. The Kohne Square of Isfahan, which was ruined completely, was of the main elements of Isfahan in the Middle Ages. Around the Kohne Square, there were various elements, such as mosques, schools, palaces, markets, Qeysarie and Naqareh house, most of them existed up to the seventeenth century [40]. Although the plan of the Naqshe Jahan Square as the new center of the city and the symbol of the powerful government of Safavid, was derived from the plans of Kohne Square, Isfahan, Hasan Padeshah Square, Tabriz and Aali Qapu Square, Qazvin, an order was imposed to this old plan and geometric and spatial composition of elements inside and surrounding the square were carefully addressed in details. These can be compared with the geometric accuracy and spatial proportions raised to create symbolic spatial organization and urban spaces in the Renaissance and afterwards by people such as Leonardo da Vinci and Michelangelo [18]. It can be said that the Naqshe
Jahan Square brought government (A'ali Qapu), religious (Imam and Sheikh Lotfollah Mosques), commercial (market) elements and city together and make connection between them [38].

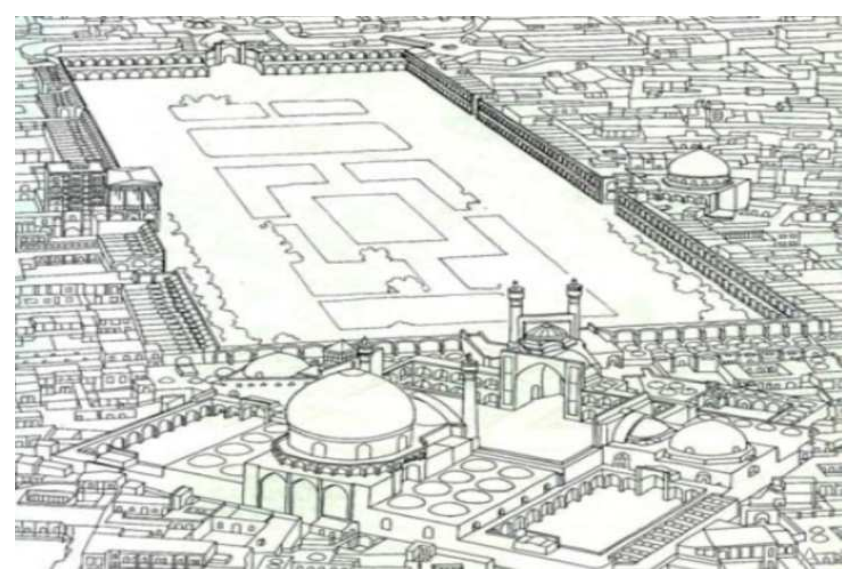

Figure 3. Naghsh-e Jahan Square.

Table 2. Comparison of the squares of Samarkand city in the Timurid era and Isfahan city in the Safavid era.

\begin{tabular}{lll}
\hline & Main activity and function & Main design pattern \\
\hline \multirow{4}{*}{ Samarkand } & a) Cultural & a) Predesigned \\
& b) Commercial & b) Emphasis on the scale \\
c) Social & c) Emphasis on the facades and placing of minarets in the corner and omitting any \\
d) Governmental & connection between the square construction and other buildings \\
e) Public celebrations & d) Simplification of building form \\
a) Governmental & a) Designing of the walls of square and in accordance with its function \\
b) Religious & b) Predesigned \\
& c) Social & c) Having regular geometric plan as a rectangle
\end{tabular}

\section{Conclusion}

The two cities of Samarkand in the Timurid period and Isfahan in the Safavid period had the same natural, climatic, social, cultural and economic characteristics, which had significant effects on the formation of urban spaces in both cities. The urban spaces of these cities have been formed with an emphasis on nature (specially, water and vegetation) and human. The Timurids took the government with a lot of chaos, but they have been quickly attracted to the culture and civilization of Iran. Then, they increased their richness and influenced the urban spaces built in the Safavid era. The Timurid cities (Herat and Samarkand) have also influenced the design of the Safavid urban spaces. Shah Abbas was born in Herat in $978 \mathrm{AH}$ and lived there until the beginning of his reign. Hence, the Herat city played a key role in forming his thought of utopia. Shah Abbas probably considered the garden of Herat as the primary pattern when he ordered the development of Isfahan city with the use of Iranian pattern. The growing support of art and artist and the creation of new places for the spread of culture and art along with religious beliefs influenced by the Sufi thought of that time undoubtedly make the Timurid urban spaces one of the milestones of urbanism. The features of Timurid urban spaces can be mentioned as several principles: the establishment of gardens within and outside the city, the construction of main urban roads using various buildings and varies land uses, the spread of urban complexes using a square. Then, in the Safavid era, urban spaces flourished by following the Isfahan school. In this way, the elements, formed in the earlier periods, evolved in the Safavid era. Many of the urban space of the Isfahan school, such as the squares, main roads of the city, the garden complexes, were formed before the appearance of Isfahan school. Then, with the development of social, political, economic and cultural grounds and composition of them in the urban spaces, the ideal city of Isfahan was realized in the Safavid era. It seems that the principals of physical and semantic formation of urban spaces of Isfahan city in the Safavid era had aimed to create the heavenly paradise in the present world.

\section{References}

[1] Aghabozorg, N. Motedayen, H. (2015). Theoretical Origin of Naghshan-e Jahan Square, Bagh Nazar, No. 11.

[2] Alaei, S. (2016). Investigating and Influencing the Architecture and Gardening of the Safavid Period in Elgoli Garden in Tabriz, Art And Architecture Studies, Nos. $1 \& 2$. 
[3] Alami, M. (2011). Symbolism of Iranian garden, Translated by Shahrzad Khademi. Landscape Magazine, No. 33.

[4] Alami, M. Safavian Gardens a Stage for Displaying Royal Rites and political Legitimacy, Translated by Rezaipour, M. and Jeyhani, HR. Golestan Art.

[5] Ansari, M. (2003). Iranian Garden in History, Proceedings of the Isfahan and Safavid Conference, Vol. 2, University of Isfahan Publication.

[6] Ansari, M. (2000). Values of Iranian Garden (Safavian Isfahan), Doctoral Thesis, Department of Architecture, Faculty of Fine Arts, Tehran University.

[7] Ayatollahi, H. (2001). Iran Book: History of Art, Tehran: AlHoda International Publications.

[8] Blair, Sh. (2007). Bloom, J. Islamic Art and Architecture; Translated by Jaghob Ajend, Second Edition, Tehran, Samt Publication.

[9] Blair, S. Bloom, J, M. (2003) Islamic art and architecture in Iran and central Asia, $\operatorname{Tr}$ Mohammad Moosa Hashemi Golpayegani, Tehran, Vezarate Farhang va Ershad Eslami.

[10] Browne, k. Granville, E. (1966). A literary, history of Persia, Tr Rashid Yasemi, Vol (4), Tehran, Ebne sina.

[11] Chardin, J. (1996). Chardin Travelogue, Translated by: Yaghmaei, I., Tehran: Toos Publication.

[12] Estakhri, A. (1994). Countries and Creeds, translation by Mohammed bin Asad bin Abdullah Testri, Bija: Endowment by Dr. Mahmoud Afshar.

[13] Farnood, M. (2014). The Role of the Square in Urban Space; From Aguara to Liberty Square.

[14] Foroutan, M. (2009). An Analysis of Urban Spaces From Tabriz in Ilkhanian Era to Isfahan Safavi Era, (Exploring social, economic, political and cultural contexts), City Identity Magazine, No. 9.

[15] Gholipour, S. Heydar Nattaj, V. (2016). Influences of Timurid gardens in Samarkand on Safavid gardens in Isfahan: Chahar Bagh street, Bagh Nazar.

[16] Gonzalez de Clavicho, R. (1998). Clavicho Travelogue, Translated by Massoud Rajab Nia, The Book Translation and Publishing Company.

[17] Goudarzian, Sh. (2014). Comparing the Concept of Perspective in Iranian and Indian Gardens, Art and Civilization Quarterly, No. 1.

[18] Habibi, M. (2009). From the city to the city, Tehran University Press, Second Edition.

[19] Haghighatbin, M. (2010). A Study of Design and Aesthetic Principles of Iranian Garden in Safavid Urban Indexes and Its Effect on Outside Iran, Doctoral Thesis, Department of Art Research, Tarbiat Modares University, Faculty of Art and Architecture.

[20] Haghighatbin, M. Ansari, M. Zabihian, Sh. (2011). Exploring the Principles of Howard Gardens and Comparing It with the Safavian Gardens, Naghsh-e Jahan, Second Year.

[21] Haghighatbin, M. Ansari, M. Bemanian, M. R. (2013). Investigating the Teachings of Shiite Religion in the Gardens of the Safavian Cities, Quarterly Journal of Islamic Iranian
Urban Studies.

[22] Haghighatbin, M. Ansari, M. Pour Jafar, M. (2009). Historical Study of Chahar Bagh Street in Mashhad in Safavid Era, Historical Researches, University of Isfahan, No. 9.

[23] Hanachi, P. (2012). Urban Restoration in Iranian Historical Fabrics, University of Tehran Publications, Research Institute of Art and Culture.

[24] Hekmati, J. (2002). Garden and Park Design, Tehran, Comprehensive Culture.

[25] Herdeg, K. (1997). Shape Structure in Islamic Architecture of Iran and Turkestan, Translated by Mohammad Taghizadeh Motlaq, Boom Publications, First Edition.

[26] Heydar Nattaj, V. (2009). Samarkand Gardens, Landscape.

[27] Jafari, B. (2017). Comparative Comparison of Eastern and Timurid Gardens, Rigestan Square, Samarkand, Magnificent Iranian monument.

[28] Jamalladin, Gh. (2015). The Basics and Concepts of Islamic Urban Planning in the Timurian Period: Samarkand, Harat, National Conference on Islamic Iranian Architecture and Design, Payame Noor University of Guilan.

[29] Jamshidi Kouhsari, S. (2010). State of the Art of Architecture in the Timurian Period, University of Bagher Al-Ulom (AS), No. 3.

[30] Jenabadi, M. (1999). Roozeh Al-Safwai, edited by Gholamreza Tabatabaei Majd, Tehran: Endowment Publication by Dr. Mahmoud Afshar.

[31] Khansari, M. Moghtader, M. Yavari, M. (2004). Iranian Garden, a Reflection of Paradise, Translated by Aran Consulting Engineers, Tehran: Secretariat of the International Iranian Garden Conference.

[32] Moghbeli, A. (2017). The Evolutionary System of Islamic Architecture in Central Asia in the Tenth and Eleventh Centuries AH, Naghsh-e Jahan Quarterly, No. 3.

[33] Monajem, M. J. (1987). Abbasian History, by the Efforts of Seifollah Vahidinia, Vahid Publications.

[34] Najmi, Sh. Rahimi, A. (2015). An Analytical Investigation of the Process of Islam's Entry into the Cities of Bukhara and Samarkand. Journal of Social Cultural Studies of Khorasan.

[35] Pourjafar, M. R, Haghighatbin, M. (2008). Comparative Comparison of Two Cities of Isfahan and Shahabad in the Seventeenth Century, Quarterly Journal of Urban Management, No. 21.

[36] Pourmokhtar, A. (2013). Investigating the Extent of Walkability in Esfahan's Chahar Bagh Street and Its Impact on Social Interaction of Citizens, Iranian Journal of Urban Studies.

[37] Shahabi nejad, A. Ayoubi, R. Ghalenoei, M. (2014). Historical Formation and Transformation of Naghshan-e Jahan Square in Isfahan, Professional Biannual journal on Restoration Knowledge and Cultural Heritage, No. 1.

[38] Soheili, J. (2008). From Naghsh-e Jahan to Campidolio, City Identity Magazine, Second Year.

[39] Taghizadeh, A. Eskandari, M. (2011). The Concept and Position of Urban Space in Iranian Cities and Culture, Third National Conference on Urban Development. 
[40] Tavasoli, M. Bonyadi, N. (1993). Design of Urban Spaces, Urbanization and Architect Research Center of Iran, First Edition.

[41] Tavasoli, M. Bonyadi, N. (1990). Principles and Methods of Urban Design and Residential Spaces in Iran, Center for Urban Planning Studies and Research.
[42] Wilbur, D. (2006). Iranian Gardens and its Palaces, Translated by Mahin Dokht Saba, Scientific and Cultural Publishing Company, Tehran.

[43] Wilbur, D. Gulbeck, L. (1995). Timurian Architecture in Iran and Turan, Translated by Keramatollah Afsar and Mohammad Yousef Kiani, Tehran, National Heritage Organization. 